\title{
Effect of Nano Material Lithovit on Growth, Flowering and Chemical Composition of Echinacea purpurea (L.). \\ Abd El-baset, M. M.
}

Vegetable and Floriculture Department, Faculty of Agriculture, Mansoura University, Mansoura city, Egypt. mohanedgaber@yahoo.com

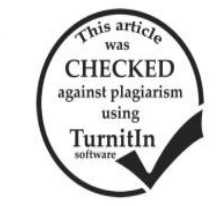

\begin{abstract}
Two field experiments at (2016-2017) seasons were conducted to study the effect of lithovit at concentrations of 1 and $2 \mathrm{~g} / 1$ for once, twice and thrice times application individually at 30 days interval to improve vegetative growth, flowering and chemical contents of Echinacea purpurea (L.) The obtained results showed that spraying Echinacea purpurea (L.) plants with lithovit at $2 \mathrm{~g} / 1$ for three times application in the form of foliar sprays at 30 days interval led to improve plant growth and yield characters expressed as plant height, number of leaves and flowers, fresh and dry weights of plant. Also, chemical constituents of N, P, K and total sugars $\%$, phenol compound and photosynthetic pigments(total chlorophyll and carotenoids). Finally, it could be recommend to treat Echinacea purpurea (L.) plants by lithovit at the concentration $2 \mathrm{~g} / \mathrm{l}$ three times as foliar spray to achieve the best results regarding vegetative growth, flowering and chemical composition of plant under Egyptian conditions.
\end{abstract}

Keywords: Echinacea purpurea, nano material and lithovit

\section{INTRODUCTION}

Echinacea purpurea (L.), commonly called purple coneflower family Asteraceae is herbaceous perennial herb and using a back view in landscaping. The light green stems have small purple streaks and scattered white hairs. The alternate or opposite leaves dark green was across, becoming smaller as they ascend the stems and considered good fresh cut or dried flower.

Nanotechnology technique is a large range of newness application in the agricultural purpoes because nanoparticles had wonderful physicochemical properties, i.e. high surface area, high reactivity, tunable pore size and particle morphology (Siddiqui et al., 2015).

Nanotechnology could be clarified as making of special activity materials, systems and devices through control of matter at a scale of 100 nanometers (nm) or less (Otles and Yalcin, 2013). Nanomaterial fertilizers give more effects cover increased root and shoot length as well as seedlings vegetative biomass in some vegetable plants (Rico et al., 2011). Nano-materials have an important role in avert degradation environment agrochemicals, minimize the fertilizers quantities, reduced costs and control excess chemicals (Ditta, 2012 and Grover et al., 2012). lithovit compound is a natural calcium carbonate (nano- $\mathrm{CaCO}_{3}$ ) nano-fertilizer as a foliar fertilizer, containing $75 \%$ calcium carbonate, 5\% silica, 4\% magnesium carbonate and particles extremely small from natural limestone deposits, that enhance their ability to enter plant stomata, when spraying (Cai et al., 2009).

The present study was carried out to evaluate the effect of concentration and number of foliar sprays of nanomaterial lithovit on growth, flowering and chemical composition of Echinacea purpurea (L.)

\section{MATERIALS AND METHODS}

A field experiment was conducted during two successive seasons of 2016 and 2017 at Nursery of Table 1. Main characteristics of lithovit ${ }^{\circledR}$ used in the study:

\begin{tabular}{lccc} 
Component (\%) & Value & Component (\%) & Value \\
\hline Calcium carbonate & 79.19 & Nitrogen & 0.06 \\
Clay & 0.79 & Phosphate & 0.01 \\
Copper & 0.002 & Potassium oxide & 0.21 \\
Iron & 1.31 & Selisium dioxide & 11.41 \\
Magnesiumcarbonate & 4.62 & Sulphate & 0.33 \\
Manganese & 0.014 & Zinc & 0.005 \\
\hline
\end{tabular}

oOrnamental and Medicinal Plants and Laboratory of the Vegetable and Ornamental Plants Dept., Fac. of Agric. Mansoura Univ. Egypt to investigate the response of concentration and number of foliar sprays of nano material lithovit on growth, flowering and chemical composition of Echinacea purpurea (L.) plant.

\section{Plant material}

The plant of Echinacea purpurea (L.) seeds were obtained from Agriculture Research Center Ministry of Agriculture, Egypt. Six seeds were sown and the seeds were covered with soil, in October $5^{\text {th }}$ of each season in the open field in rows $50 \mathrm{~cm}$ apart and spacing between seedlings was about $40-50 \mathrm{~cm}$. The seeds germinated within 3 to 4 weeks after two weeks of complete germination, were thinned at one strong one then. The N, P and $\mathrm{K}(19: 19: 19)$ compound fertilizer was added as a basal dose $(1 \mathrm{~g} / 1)$ weekly for all plants until $5-8$ leaves $(15 \mathrm{~cm}$ almost) appeared on each plant.

\section{Experimental design:}

The experimental treatments were arranged in a factorial experiment as two factors (first concentration of nano material lithovit with two concentrations ( 1 and $2 \mathrm{~g} / \mathrm{l}$ ) and the second factor was number of foliar applications of nano material lithovit (control, once, twice and thrice) in a randomized complete blocks design with three replicates. Each replicate included three plants and experiment design included the interaction treatments were six treatments. Nano material lithovit analyzed and recorded in Table (1) was used as a foliar spray with concentrations of 1 and 2 $(\mathrm{g} / \mathrm{l})$ and number of foliar applications once, twice and thrice as a foliar spray individually at 30 days interval. Prior to any practices, a composite soil sample was taken from the soil surface $(0-30 \mathrm{~cm})$ of the experimental site, air- dried, sieved by $2 \mathrm{~mm}$ sieve and analyzed and recorded in Table (2).

Chemical analysis of lithovit ${ }^{\circledR}$ according to Hamoda et al. (2016). 
Table 2. Physical and chemical analysis of the soil before the application of any treatments in the experiment.

\begin{tabular}{|c|c|c|c|c|c|c|c|c|c|c|c|}
\hline \multirow{2}{*}{ seasons } & \multicolumn{4}{|c|}{ Mechanical analysis (\%) } & \multirow{2}{*}{$\begin{array}{c}\text { Texture } \\
\text { class }\end{array}$} & \multirow{2}{*}{$\begin{array}{c}\mathrm{CaCO3} \\
\%\end{array}$} & \multirow{2}{*}{$\begin{array}{c}\text { EC dS.m- } \\
11: 5\end{array}$} & \multirow{2}{*}{$\begin{array}{c}\mathrm{pH} \\
(1: 2.5)\end{array}$} & \multicolumn{3}{|c|}{ Available (ppm) } \\
\hline & oarse Sand & Fine Sand & Silt & Clay & & & & & $\mathbf{N}$ & $\mathbf{P}$ & $\mathbf{K}$ \\
\hline st & 1.51 & 25.96 & 38.19 & 31.55 & Clay & 3.13 & 0.96 & 8.14 & 43.9 & 5.92 & 287.5 \\
\hline 2nd & 1.85 & 26.95 & 39.11 & 31.43 & loamy & 2.79 & 1.08 & 7.94 & 45.2 & 6.13 & 293.5 \\
\hline
\end{tabular}

The harvest was done from May $24^{\text {th }}$ to July $1^{\text {th }}$ (after flowering) in both seasons.

Data recorded:

1. Morphological characters:

Plant height $(\mathrm{cm})$.

Number of leaves and flowers /plant.

Fresh and dry matter of shoots (g/plant).

2. Chemical determination analysis:

Nutrient elements determination from the dry plant samples:

-N\% determined by modified micro Kjeldahle method as described by Pregl (1945).

-P\% determined according to Jackson (1967).

-K\%determined was estimated using Spectrophotometer

(A Perkin-Elmer, Model2380.USA) according to the methods of Chapman and Pratt (1982).

Total sugars $\%$ was determined according to the method described by Sadasivam and Manickam, (1996).

Total phenol compound $(\mathrm{mg} / 100 \mathrm{~g} \mathrm{dw})$ was carried out with the Folin-ciocalteau reagent according to Malick and Singh (1980).

Pigments content (mg/g fw):Total chlorophylls and carotenoids were determined in leaf samples (mg / $\mathrm{g}$ fresh matter) according to Mackinney (1941).

Statistical analysis:

The experimental design was a factorial experiment in a randomized complete blocks design according to Steel and Torrie (1980). The statistical software package

Table 3. Effect of lithovit concentration, number of foliar applications and their interactions on plant height, leaf number and flower number of Echinacea plants during the two seasons of 2016 and 2017.

\begin{tabular}{|c|c|c|c|c|c|c|c|}
\hline \multicolumn{8}{|c|}{ Vegetative growth parameters } \\
\hline \multirow[b]{2}{*}{ Treatments } & \multirow[t]{2}{*}{ Characters } & \multicolumn{2}{|c|}{ Plant height(cm.) } & \multicolumn{2}{|c|}{ Leaf number } & \multicolumn{2}{|c|}{ Flower number } \\
\hline & & 2016 & 2017 & 2016 & 2017 & 2016 & 2017 \\
\hline \multicolumn{8}{|c|}{ A- concentration: } \\
\hline $1 \mathrm{~g} / 1$ & & 80.83 & 73.42 & 75.50 & 66.67 & 5.92 & 5.75 \\
\hline $2 \mathrm{~g} / 1$ & & 93.67 & 90.75 & 96.80 & 98.42 & 11.67 & 11.00 \\
\hline F. test & & $\mathrm{S}$ & $\mathrm{S}$ & $\mathrm{S}$ & $\mathrm{S}$ & $\mathrm{S}$ & $\mathrm{S}$ \\
\hline \multicolumn{8}{|c|}{ B- Number of foliar applications } \\
\hline 0 & & 70.67 & 62.33 & 41.00 & 44.33 & 3.67 & 4.33 \\
\hline Once & & 85.17 & 80.67 & 93.80 & 80.00 & 8.00 & 7.83 \\
\hline Twice & & 92.00 & 88.33 & 93.70 & 96.17 & 9.33 & 8.50 \\
\hline Thrice & & 101.17 & 97.00 & 116.00 & 109.67 & 14.17 & 12.83 \\
\hline L.S.D $5 \%$ & & 2.21 & 5.12 & 10.15 & 4.71 & 1.31 & 2.26 \\
\hline \multicolumn{8}{|c|}{ c- Interactions: } \\
\hline & Once & 78.67 & 72.33 & 84.00 & 61.67 & 5.33 & 5.67 \\
\hline \multirow[t]{3}{*}{1} & Twice & 85.33 & 77.33 & 70.30 & 74.00 & 6.00 & 5.67 \\
\hline & Thrice & 88.67 & 81.67 & 106.70 & 86.67 & 8.67 & 7.33 \\
\hline & Once & 91.67 & 89.00 & 103.70 & 98.33 & 10.67 & 10.00 \\
\hline \multirow[t]{2}{*}{2} & Twice & 98.67 & 99.33 & 117.00 & 118.33 & 12.67 & 11.33 \\
\hline & Thrice & 113.67 & 112.33 & 125.30 & 132.67 & 19.67 & 18.33 \\
\hline L.S.D $5 \%$ & & 3.12 & 7.24 & 14.35 & 6.67 & 1.48 & 3.20 \\
\hline
\end{tabular}

leaf number:

Data presented in the same Tables showed that $2 \mathrm{~g} / \mathrm{l}$

lithovit as three foliar applications significantly increased
GenStatver 11 ( Lawes Agricultural Trust, Rothamsted Experimental Station, UK) computer program was used. The treatment means were compared using the least significant difference (LSD) at 0.05 level, as described by Gomez and Gomez (1984).

\section{RESULTS AND DISCUSSION}

Vegetative growth parameters:

Effect of concentration:

Data presented in Tables (3and4) showed that all measured characters of plant height $(\mathrm{cm}$.), leaf and flower number, fresh and dry weight (g/plant) were significantly affected by $2 \mathrm{~g} / 1$ lithovit during the two seasons of this study comparing with $1 \mathrm{~g} / \mathrm{l}$ treatment.

Effect of foliar number application:

The same Tables revealed that application of lithovit as three times foliar gave highest number of flowers which may be due to the height of the plant and the increase in the number of leaves, fresh and dry weight (g/plant) in the both seasons, compared to the other treatments and control in this field.

Effect of interactions:

plant hight:

Data presented in Table (3) showed that plants treated with $2 \mathrm{~g} / \mathrm{l}$ of lithovit as three foliar applications resulted in the greatest significant increase in plant hight than the other tested doses of lithovit $(113.67 \mathrm{~cm}$.). In the

second season the same trend was observed. ters

liar application dose of lithovit.

In addition, using $2 \mathrm{~g} / 1$ lithovit as twice or thrice foliar applications resulted in the highest significant leaf 
number in the first and second seasons(117.0,118.33,125.3 and 132.67 respectively) than $2 \mathrm{~g} / \mathrm{l}$ lithovit as once foliar application.

\section{Flower number:}

Data presented in Table (3) showed that the same trends of results of leaf and flower number showed like trends of flower number as a wonderful increase was achieved with $2 \mathrm{~g} / 1$ lithovit as three foliar applications (19.67) when compared with once and twice foliar application of the same concentration (10.67 and 12.67 flowers), respectively. It was a matter of interest to note that the increase with three foliar applications reached more than other foliar applications with lithovit.

In this respect, it may be added that $2 \mathrm{~g} / \mathrm{l}$ lithovit increased the flowers about $50 \%$ than those treated with $1 \mathrm{~g} / 1$ lithovit.

Actually, the increase in number of flower means achieved a preferable and superior quality
Fresh and dry weight (g/plant):

Data presented in Table (4) cleared that treated plants with $2 \mathrm{~g} / \mathrm{l}$ lithovit as three foliar applications significantly increased fresh and dry weight values in both seasons followed by treating plants with $2 \mathrm{~g} / \mathrm{l}$ lithovit as twice foliar application, compared with other used treatments in this study. However, the control plant produced the lowest values during the two seasons.

(Rawat and Melkania,2015) found that $\mathrm{CO}_{2}$ stimulates the increase in plant growth parameter in response to lithovit which might be due to, its role as a long term reservoir supplying plant with $\mathrm{CO}_{2}$ (Kumar,2011). Thus, it can improve plant growth and productivity, where elevated $\mathrm{CO}_{2}$ concentrations generally increased carbon assimilation, biomass and leaf number of plant (Maswada and Abd El-Rahman 2014). Lithovit particles remain as a thin layer on the surface of leaves and penetrate frequently when they get wet with dew at night.

Table 4. Effect of lithovit concentration, number of foliar applications and their interactions on fresh and dry weight (g/plant) of Echinacea plants during the two seasons of 2016 and 2017.

\begin{tabular}{|c|c|c|c|c|c|}
\hline \multicolumn{6}{|c|}{ Vegetative growth parameters } \\
\hline \multirow[b]{2}{*}{ Treatments } & \multirow[t]{2}{*}{ Characters } & \multicolumn{2}{|c|}{ Fresh weight (g/plant) } & \multicolumn{2}{|c|}{ Dry weight (g/plant) } \\
\hline & & 2016 & 2017 & 2016 & 2017 \\
\hline \multicolumn{6}{|c|}{ A- Concentration: } \\
\hline $1 \mathrm{~g} / 1$ & & 153.90 & 148.60 & 54.70 & 47.20 \\
\hline $2 \mathrm{~g} / 1$ & & 250.20 & 220.90 & 80.90 & 74.90 \\
\hline F. test & & $\mathrm{S}$ & $\mathrm{S}$ & $\mathrm{S}$ & $\mathrm{S}$ \\
\hline \multicolumn{6}{|c|}{ B- Number of foliar application } \\
\hline 0 & & 84.60 & 106.30 & 38.70 & 41.30 \\
\hline Once & & 167.90 & 171.20 & 63.30 & 57.80 \\
\hline Twice & & 248.20 & 195.10 & 73.40 & 63.30 \\
\hline Thrice & & 307.50 & 266.60 & 95.60 & 81.60 \\
\hline L.S.D $5 \%$ & & 34.76 & 32.55 & 18.79 & 19.66 \\
\hline \multicolumn{6}{|c|}{ c- Interactions: } \\
\hline \multirow{4}{*}{1} & Once & 137.20 & 139.80 & 52.80 & 42.90 \\
\hline & Twice & 188.10 & 161.40 & 58.10 & 51.40 \\
\hline & Thrice & 205.60 & 187.20 & 69.10 & 53.00 \\
\hline & Once & 198.60 & 202.60 & 73.80 & 72.70 \\
\hline \multirow[t]{2}{*}{2} & Twice & 308.40 & 228.90 & 88.80 & 75.20 \\
\hline & Thrice & 409.30 & 346.00 & 122.20 & 110.30 \\
\hline L.S.D $5 \%$ & & 49.16 & 46.04 & 26.58 & 27.80 \\
\hline
\end{tabular}

Chemical determination analysis:

Nutrient elements determination:

Minerals (N, P, K, total sugars (\%) and phenols (mg/100g dw):

Effect of concentration:

Data presented in Table (5) showed that Echinacea purpurea (L.) treated $2 \mathrm{~g} / 1$ lithovit significantly increased $\mathrm{N}$ $\mathrm{P} \mathrm{K} \%$, total sugars $\%$ and phenols in both seasons more than the lower used doses.

Effect of number applications:

Data presented in Table (5) indicated that increasing the spray number of lithovit led to increase chemical content N P K, total sugars\% and phenols in both seasons, with three applications gave significant differences compared to other treatments and control.

\section{Effect of interactions:}

Data recorded in Table (5) showed that treated plants with high level at $2 \mathrm{~g} / \mathrm{l}$ lithovit for thrice foliar applications gave the significantly highest significant nitrogen values (3.09 and $3.20 \%$ ), respectively in both seasons when compared with other treatments.

The importance of nitrogen was attributed to relatively large quantities required in connection with all growth processes in plants.

All other estimates like phosphorus, potassium, total sugars $\%$ and phenols, in the same table clearly indicated that they were nearly as the same as observed in the nitrogen $\%$.

In this respect, Byan (2014) on snap bean plants indicated that foliar spraying with lithovit improved chemical constituents of plant, i.e., nitrogen, phosphorus and potassium $\%$ as compared to normal water (control). 
Table 5. Effect of lithovit concentration, number of foliar applications and their interactions on N, P, K, total sugar(\%) and phenols (mg/100g dry weight) of Echinacea plants during the two seasons of 2016 and 2017.

\begin{tabular}{|c|c|c|c|c|c|c|c|c|c|c|c|}
\hline \multicolumn{12}{|c|}{ Chemical constituent parameters } \\
\hline \multirow[b]{2}{*}{ Treatments } & \multirow[t]{2}{*}{ Characters } & \multicolumn{2}{|c|}{$\begin{array}{c}\mathbf{N} \\
(\%)\end{array}$} & \multicolumn{2}{|c|}{$\begin{array}{c}\mathbf{P} \\
(\%)\end{array}$} & \multicolumn{2}{|c|}{$\begin{array}{c}\mathbf{K} \\
(\%)\end{array}$} & \multicolumn{2}{|c|}{$\begin{array}{c}\text { Total soluble } \\
\text { sugar(\%) }\end{array}$} & \multicolumn{2}{|c|}{$\begin{array}{c}\text { Phenols } \\
\text { (mg/100g dry weight) }\end{array}$} \\
\hline & & 2016 & 2017 & 2016 & 2017 & 2016 & 2017 & 2016 & 2017 & 2016 & 2017 \\
\hline \multicolumn{12}{|c|}{ A- Concentration: } \\
\hline $1 \mathrm{~g} / 1$ & & 2.28 & 2.36 & 0.21 & 0.22 & 2.53 & 2.34 & 17.90 & 17.75 & 2233.00 & 2251.40 \\
\hline $2 \mathrm{~g} / 1$ & & 2.54 & 2.63 & 0.24 & 0.24 & 2.75 & 2.60 & 18.38 & 18.18 & 2254.60 & 2274.90 \\
\hline F. test & & $\mathrm{S}$ & $\mathrm{S}$ & $\mathrm{S}$ & $\mathrm{S}$ & $\mathrm{S}$ & $\mathrm{S}$ & $\mathrm{S}$ & $\mathrm{S}$ & $\mathrm{S}$ & $\mathrm{S}$ \\
\hline \multicolumn{12}{|c|}{ B- Number of foliar application } \\
\hline 0 & & 1.87 & 1.98 & 0.18 & 0.18 & 2.07 & 1.91 & 17.20 & 17.06 & 2196.30 & 2216.30 \\
\hline Once & & 2.16 & 2.27 & 0.21 & 0.21 & 2.47 & 2.24 & 17.73 & 17.58 & 2223.70 & 2242.20 \\
\hline Twice & & 2.70 & 2.76 & 0.25 & 0.25 & 2.94 & 2.77 & 18.64 & 18.44 & 2268.00 & 2287.30 \\
\hline Thrice & & 2.90 & 2.98 & 0.27 & 0.27 & 3.10 & 2.97 & 18.98 & 18.77 & 2287.20 & 2306.80 \\
\hline L.S.D $5 \%$ & & 0.10 & 0.10 & 0.01 & 0.01 & 0.10 & 0.09 & 0.15 & 0.14 & 12.65 & 10.84 \\
\hline \multicolumn{12}{|c|}{ c- Interactions: } \\
\hline & Once & 2.05 & 2.17 & 0.20 & 0.20 & 2.37 & 2.14 & 17.55 & 17.41 & 2216.00 & 2233.30 \\
\hline \multirow[t]{3}{*}{1} & Twice & 2.49 & 2.54 & 0.23 & 0.24 & 2.75 & 2.55 & 18.24 & 18.09 & 2251.00 & 2269.00 \\
\hline & Thrice & 2.71 & 2.75 & 0.25 & 0.26 & 2.91 & 2.77 & 18.60 & 18.44 & 2268.70 & 2287.00 \\
\hline & Once & 2.27 & 2.36 & 0.21 & 0.22 & 2.56 & 2.35 & 17.91 & 17.75 & 2231.30 & 2251.00 \\
\hline \multirow[t]{2}{*}{2} & Twice & 2.91 & 2.98 & 0.27 & 0.27 & 3.12 & 2.98 & 19.04 & 18.79 & 2285.00 & 2305.70 \\
\hline & Thrice & 3.09 & 3.20 & 0.28 & 0.29 & 3.26 & 3.16 & 19.35 & 19.10 & 2305.70 & 2326.70 \\
\hline L.S.D $5 \%$ & & 0.15 & 0.14 & 0.02 & 0.01 & 0.15 & 0.13 & 0.22 & 0.20 & 17.88 & 15.33 \\
\hline
\end{tabular}

Pigments content (total chlorophyll and carotenoids):

Chlorophyll contributes by far the amount of total photosynthates for plant growth and the prop able role of carotenoides in plants its relation with vitamin A manufacture. Recently two functions were discovered. The first one is protection against photo oxidation of chlorophyll. The second is transferring energy to chlorophyll A.

Effect of concentration:

As for effect of the lithovit concentration and their foliar number applications on total chlorophyll and carotene data presented in Table (6) showed that using the $2 \mathrm{~g} / \mathrm{l}$ lithovit produced the highest significant values of total chlorophyll and carotenoids of (36.08 and $11.71 \mathrm{mg} / \mathrm{g}$. fw) respectively, followed by $1 \mathrm{~g} / 1$ lithovit recording 30.43 and $11.27 \mathrm{mg} / \mathrm{g}$., respectively, in the first season and the second season was similar to the same results obtained in the first one.

Effect of foliar number application:

In the same Table data cleared that lithovit was used as thrice foliar applications gave significant increase of total chlorophyll and carotenoids (39.57 and $12.00 \mathrm{mg} / \mathrm{g}$ fw), respectively in first season but there was significant difference between using this application and other 0,1 and 2 foliar applications. In the second season there were nonsignificant differences between using twice and three foliar applications of lithovit.

Table 6. Effect of lithovit concentration, number of foliar applications and their interactions on photosynthetic pigments of total chlorophyll and carotenoids ( $\mathrm{mg} \backslash \mathrm{g}$ fw) of Echinacea plants during the two seasons of 2016 and 2017.

\begin{tabular}{|c|c|c|c|c|c|}
\hline \multicolumn{6}{|c|}{ Photosynthetic pigments(total chlorophyll and carotenoids) } \\
\hline \multirow{2}{*}{\multicolumn{2}{|c|}{ Characters }} & \multicolumn{2}{|c|}{$\begin{array}{c}\text { Total chlorophyll } \\
(\mathrm{mg} \backslash \mathrm{g} f \mathrm{w})\end{array}$} & \multicolumn{2}{|c|}{$\begin{array}{c}\text { Carotenoids } \\
(\mathrm{mg} \backslash \mathrm{g} \text { fw })\end{array}$} \\
\hline & & 2016 & 2017 & 2016 & 2017 \\
\hline \multicolumn{6}{|c|}{ A- Concentration: } \\
\hline $1 \mathrm{~g} / 1$ & & 30.43 & 33.79 & 11.27 & 11.23 \\
\hline $2 \mathrm{~g} / 1$ & & 36.08 & 37.39 & 11.71 & 11.42 \\
\hline F. test & & $\mathrm{S}$ & $\mathrm{S}$ & $\mathrm{S}$ & $\mathrm{S}$ \\
\hline \multicolumn{6}{|c|}{ B- Number of foliar application } \\
\hline 0 & & 24.24 & 25.82 & 10.96 & 10.66 \\
\hline Once & & 33.15 & 37.36 & 11.34 & 11.34 \\
\hline Twice & & 36.05 & 38.53 & 11.65 & 11.61 \\
\hline Thrice & & 39.57 & 40.64 & 12.00 & 11.67 \\
\hline L.S.D $5 \%$ & & 2.47 & 3.42 & 0.43 & 0.40 \\
\hline \multicolumn{6}{|c|}{ c- Interactions: } \\
\hline \multirow{4}{*}{1} & Once & 29.56 & 35.20 & 11.12 & 11.20 \\
\hline & Twice & 32.20 & 36.19 & 11.61 & 11.51 \\
\hline & Thrice & 35.70 & 37.96 & 11.41 & 11.54 \\
\hline & Once & 36.75 & 39.53 & 11.57 & 11.49 \\
\hline \multirow[t]{2}{*}{2} & Twice & 39.90 & 40.88 & 11.71 & 11.71 \\
\hline & Thrice & 43.44 & 43.33 & 12.59 & 11.80 \\
\hline L.S.D $5 \%$ & & 3.50 & 4.83 & 0.61 & 0.57 \\
\hline
\end{tabular}




\section{Effect of interactions:}

In both seasons chlorophylls and carotenoids were increased as a result of the different treatments from spraying the plants with Lithovit in (Table 6). The highest values were obtained by spraying plants with $2 \mathrm{~g} / \mathrm{l}$ at thrice with increased reached (43.44and $12.59 \mathrm{mg} / \mathrm{g} \mathrm{fw}$ ) with a significant value in the first season for total chlorophyll and carotenoids, respectively as compared to control . The same trend was found during the second season.

Lithovit natural $\mathrm{CO}_{2}$ foliar fertilizer was a new nanotechnological fine powdered created by tribodynamic activation and micronization. Lithovit particles, sprayed finely onto the leaf surface, were taken up directly through the stomata and converted into carbon dioxide. In that way lithovit could considerably increase the photosynthesis rate, since the essential factor limiting photosynthesis, leading to yield increases.

These results were parallel with those reported by Byan (2014) and Cai et al., (2009). Positive effects of lithovit might be due to its magnesium content, which was the central component in chlorophyll molecule.

In this concern, Abdel Nabi et al. (2017) found that applying nanomaterials as a foliar application on head lettuce plants (lithovit) gave the maximum values of all studied characters, except for $\mathrm{NO}_{3}$ and $\mathrm{NO}_{2}$ contents as compared to control.

\section{Discussion}

In this study, the improving effects of lithovit mode of action is to increase $\mathrm{CO}_{2}$ levels within the plant leaf structure and by implication enhance photosynthetic efficiency. The additional supply of micronutrients from the lithovit complex, provides a source of key plant available elements required to aid photosynthetic activity. The observed increase in both production and dry matter due to the increased carbohydrates produced remaining in the canopy and flowers where plant physiological processes participate the additional carbohydrate resources in an unconstrained manner to roots, stem and leaves. This natural plant partitioning response may result in improved plant health as additional carbohydrate resource distributed within the plant and provided energy to support root growth, flowering cycle and resource to expend against insect and disease attack. If increased carbohydrates production, as a result of lithovit application elevating the $\mathrm{CO} 2$ environment at the leaf, is driving the observed productivity and dry matter increases, then the additional benefits to general plant health which accrued from increased carbohydrate resources retained within the plant, providing for a healthier plant.

It could be concluded that the effect of lithovit is improving the positive effects by supplying the $\mathrm{CO}_{2}$ in the nano form.

\section{CONCLUSION}

From the aforementioned study, it could be recommended that using spraying plants with $(2 \mathrm{~g} / \mathrm{l})$ lithovit at thrice at 30 days interval of Echinacea purpurea (L.) plants with N, P and K (19:19:19) compound fertilizer was added as a basal dose (1g/l) weekly for all plants at the recommended dose gave the highest values of plant growth, yield of flower, chemical constituents and increasing yield quantity and quality under Dakahlia Governorate conditions, Egypt.

\section{REFERENCES}

Abdel Nabi, H. M. E.; Dawa K. K.; El-Gamily E. E. and Imryed Y.F.E. (2017). Effect of magnetized water, foliar application with nano material and nitrogen levels on productivity and quality of head lettuce. Int. J. Adv. Res. Biol. Sci., 4(5): 171-181.

Byan, Usrya A.I. (2014). Influence of using some safety materials on water requirement and water use efficiency of snap bean plant. J. Agric. Sci., Ain Shams Univ., Cairo, 22(2): 381-394.

Cai, K. ; Gao D. ; Chen J. and Luo S. (2009). Probing the mechanisms of silicon-mediated pathogen resistance. Plant Signaling and Behavior, 4:1-3.

Chapman, H. D., and Pratt, F. P. (1982). Determination of Minerals by Titration Method. Methods of Analysis for Soils, Plants and Water, 2nd edn.Oakland, CA: Agriculture Division, California University, 169170

Ditta, A. (2012). How helpful is nanotechnology in agriculture. Adv. Nat. Sci. Nanosci. Nanotechnol., 3: $10-11$.

Gomez, K.A. and Gomez A.A.(1984).Statistical Procedures. Agric. Res. 2nd Ed. Johnwiley and Sons, Inc, New York, USA.

Grover, M. ; Singh S.R. and Venkateswarlu B. (2012). Nanotechnology: scope and limitations in agriculture. Int. J. Nanotechnol. Appl., 2: 10-38.

Hamoda S.A.; Attia A.N., El-Hendi M.H. and El-Sayed S.O. (2016). Effect of nano-fertilizer (lithovit) and potassium on growth,fruiting and yield of Egyptian cotton under different planting dates. Int. J. Adv. Res. Biol. Sci., 3:29-49

Jackson, M.L.(1967).“ Soil Chemical Analysis, Dept. of Soils, Wise Univ., Madison 6, Wischensen, U.S.A

Kumar P. (2011).Nanotechnology in agriculture. Financing Agriculture, 34:8-10.

Mackinney, G. (1941). Absorpation of light by cholorphyll solution. J. Bio. Chem., 140:315-332.

Malick , C. P. and Singh M. B. (1980). Ins .Plant Enzymology and Histo Enzymology , Kalyani Publishers, New Delhi ,286pp.

Maswada Hanafey F. and Abd El-Rahman L. A. (2014). Inducing salinity tolerance in wheat plants by hydrogen peroxide and lithovit "A nano-CaCO3 fertilizer ". J. Agric. Res. Kafr El-Sheikh Univ., 40 (4) 696-719.

Otles, S. and Yalcin B.(2013). Food chemistry and nanoscience. J. Nanomater Mol. Nanotechnol., 2: 4 Patel PD (2002), Bio sensors for measurement of analytes implicated in food safety: a review. Trend Anal. Chem., 21(2): 96-115.

Pregl, F.(1945)."Quantitative Organic Microanalysis 4th.” Ed. I. Chudrial, London.

Rawat N. and Melkania U. (2015). Effect of increased level of $\mathrm{Co}_{2}$ on growth and yield of wheat crop. International Journal of Current Research 7: 22261- 22265. 
Rico, C.M.; Majumdar S.; Duarte-Gardea M.; PeraltaVidea J.R. and Gardea-Torresdey J.L. (2011) . Interaction of nanoparticles with edible plants and their possible implications in the food chain. J. Agric Food Chem., 59(8): 3485-3498.

Sadasivam, S. and Manickam A. (1996). Biochemical Methods, second edition, New Age Inter. India.
Siddiqui M.H.; Al-Whaibi M.H.; Firoz M; Al-Khaishany M.Y. (2015) Role of Nanoparticles in Plants. In: Siddiqui $\mathrm{MH}$ et al. (Eds.),Nanotechnology and Plant Sciences, Springer International Publishing, Switzerland, p. 19-35

Steel, R.G.D. and Torrie G.H.(1980). Principles and Procedures of Statistics, 2nd Ed. McGraw-Hill, book Co. Inc. New York, U.S.A. 633 pp.

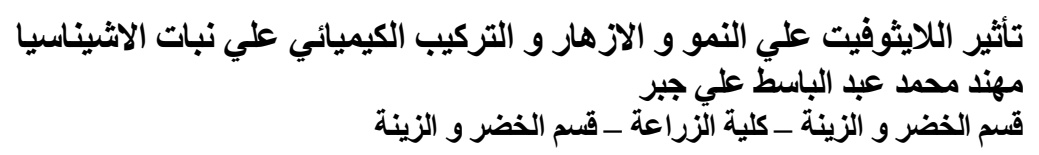

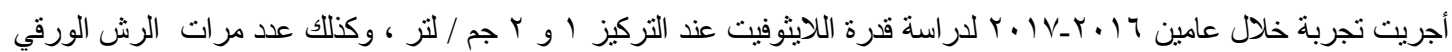

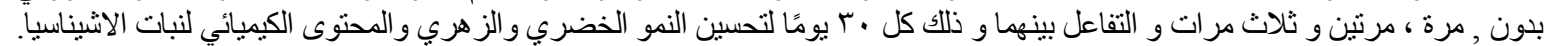

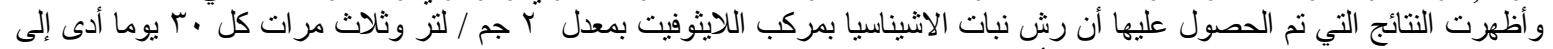

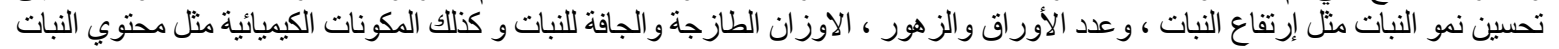

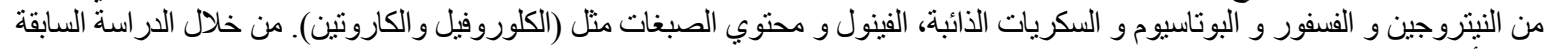

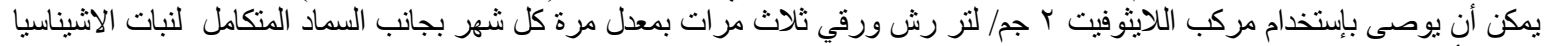

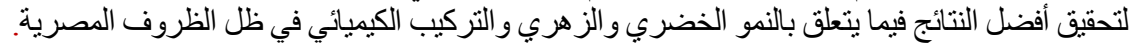

